15 Hitman GA, Sachs J, Cassell P, et al. A DR3-related DX $\times$ gene polymorphism strongly associates with insulin-dependent diabetes mellitus. Immunogenetics 1986;23:47-51.

16 Barnett AH, Eff C, Leslie RDG, Pyke DA. Diabetes in identical twins: a study of 200 pairs. Diabetologia 1981;20:87-93.

17 Bottazzo GF, Pujol-Borrell R, Gale E. Etiology of diabetes: the role of autoimmune mechanisms. In: Alberti KGMM, Krall LP, eds. Diabetes annual 1. Amsterdam: Elsevier, 1985:16-52.

18 Heaton DA, Millward BA, Gray P, et al. Evidence of B cell dysfunction which does not lead on to diabetes: a study of identical twins of insulin dependent diabetics $\mathrm{Br} M e d \mathrm{f}$ 1987;294:145-6.

19 Irvine WJ, Sawers JSA, Feek CM, Prescott RJ, Duncan LJP. The value of islet cell antibody in predicting secondary failure of oral hypoglycaemic treatment. $\mathcal{F}$ Lab Clin Immunol 1979;2:23-6. Simpson NE. Heritabilities of liability to diabetes when sex and age at onset are considered. Ann Hum Genet 1969;32:283.

21 Köbberling J, Tillil H. Empirical risk figures for first-degree relatives of non-insulin-dependent diabetics. In: Köbberling J, Tattersall R, eds. The genetics of diabetes mellitus. London:

22 Baird JD. Is obesity a factor in the aetiology of non-insulin-dependent diabetes? In: Köbberling J, Tattersall R, eds. The genetics of diabetes. London: Academic Press, 1982:233-42.

23 West KM. Epidemiology of diabetes and its vascular lesions. New York: Elsevier, 1978:231-48.

24 Peiris AN, Mueller RA, Smith GA, Struve MF, Kissebah AH. Splanchnic insulin metabolism in obesity. Influence of body fat distribution. $\mathcal{F}$ Clin Invest 1986;78:1648-57.

25 Kirk RL, Serjeantson SW, King H, Zimmet P. The genetic epidemiology of diabetes mellitus. In: Chakraborty R, Emoke JE, eds. Diseases of complex etiology in small populations: ethnic differences and research approaches. New York: Alan R Liss, 1985:119-46.

$26 \mathrm{Keen} \mathrm{H,Track} \mathrm{NS}$. Age of onset and inheritance of diabetes: importance of examining relatives. Diabetologia 1968;4:317-24

27 Vallance-Owen J. The inheritance of essential diabetes mellitus from studies of the synalbumin insulin antagonist. Diabetologia 1966;2:248.

28 Pyke DA. Diabetes: the genetic connections. Diabetologia 1979;17:333-43.

29 Rotwein PS, Chirgwin J, Province M, et al. Polymorphism in the 5'-flanking region of the human insulin gene: a genetic marker for non-insulin dependent diabetes. $N$ Engl I Med 1983;308: 65-71.

30 O'Rahilly SP, Rudenski AS, Burnett MA, et al. Beta-cell dysfunction rather than insulin insensitivity: is the primary defect in familial type 2 diabetes? Lancet 1986;ii:360-4.

11 Reaven GM. Insulin secretion and insulin action in non-insulin-dependent diabetes mellitus: which defect is primary? Diabetes Care 1984;7(suppl 1):17-24

32 Cerasi $\mathbf{E}$, Luft $\mathbf{R}$. 'What is inherited-what is added' hypothesis for the pathogenesis of diabetes mellitus. Diabetes 1987;16:615-27.

33 Iselius L, Lindsten J, Morten NE, et al. Genetic regulation of the kinetics of glucose-induced insulin release in man. Studies in families with diabetic and non-diabetic probands. Clin Genet 1985;28:8-15.

34 Leslie RDG, Volkmann HP, Poncher M, Hanning I, Orskov H, Alberti KGMM. Metabolic abnormalities in children of non-insulin-dependent diabetics. $\mathrm{Br}$ Med $\mathcal{F}$ 1986;293:840-2.

35 Hosker JP, Matthews DR, Rudenski AS, et al. Continuous infusion of glucose with model assessment: Measurement of insulin resistance and $\beta$-cell function in man. Diabetologia 1985;28:401-11.

36 Rotter JI. The modes of inheritance of insulin-dependent diabetes mellitus or the genetics of IDDM, no longer a nightmare but still a headache. Am $\mathcal{f}$ Hum Genet 1981;33:835-51.

\section{Drug formularies in hospitals}

Hospital drug formularies provide local guidelines on using the principal drugs and are developed after discussion with senior staff. A secondary aim is to contain costs. The best formularies are educational because they highlight those drugs with which prescribers should be thoroughly familiar to ensure effective treatment and to avoid unnecessary drug induced disease. Debate during revisions of formularies is also educational. Successful implementation of a formulary also leads to more predictable patterns of prescribing and purchasing and ensures immediate availability of drugs that are used as suggested in the formulary.

The cost of drugs to the National Health Service is over $£ 2000 \mathrm{~m}$ a year for about 6000 products. ${ }^{1}$ The British National Formulary lists over 4000 drugs, and acceptance of a hospital formulary that recommends 400 key drugs has obvious potential to rationalise purchasing policies and thus achieve volume discounts. Enthusiastic advocates of hospital drug formularies can point to apparently successful schemes introduced by committed clinical pharmacologists cooperating with pharmacists and local doctors. One hospital formulary reduced drug costs by $15 \%$ in the first year in medical wards in one hospital. ${ }^{2}$ Educational pharmacopoeias operating alongside a restricted drug list have contributed to drug costs in Wandsworth being $£ 500000$ a year less than was predicted without the pharmacopoeias. "Off list" prescribing by consultants accounted for only $3 \cdot 2 \%$ of all prescribing costs. ${ }^{3}$ The annual forecast hospital drugs bill at St James's Hospital,
Leeds, was underspent when a formulary policy was supported by ward pharmacy services. ${ }^{4}$ The American Society of Hospital Pharmacists estimates that operating a formulary system-not merely producing a list-will save $17 \%$ or more on overall drug costs. As patent production expires on many single source products savings will rise to $21 \%$ or more, and on multisource products to as much as $40 \%$. $^{5}$

Yet, despite such successes, problems remain. Ridley of Social Audit, a consumer related non-profit making organisation, has highlighted some of the achievements and problems in her short but provocative report, Drugs of Choice: a Report on Drug Formularies Used in NHS Hospitals. ${ }^{1}$ Some striking findings emerge. Only 37 formularies were obtained for study, perhaps half of those thought to exist in England and Wales, despite the existence of over 200 drugs and therapeutics committees. More than three quarters of district health authorities ( $83 \%$ ) responded to a survey, and $43 \%$ of those responding claimed to have formulary systems that extended to all hospitals and covered all or virtually all drug categories. More than a third of respondents (39\%) had some restrictions on certain categories of prescribing, and $18 \%$ had no formulary system. Some health authorities admitted that they had abandoned their formularies, excused consultants from their restrictions, or had difficulties in enforcing and monitoring the recommendations. There were many similarities in the choice and range of drugs in the different formularies for the six therapeutic categories studied, and the range was much more restricted than that in the British National Formulary.

Defenders of clinical freedom argue vigorously against hospital formularies, but individual clinical freedom carries with it the responsibility to define a personal formulary and to relate it to the agreed recommendations of fellow prescribers. The drug industry has also argued against the imposition of limited lists and views successful hospital formularies as a further threat to their profitability - and hence their ability to foster research. Local factors may also act against successful implementation of hospital formularies-for example, lack of commitment by local doctors and hospital managers. The successful introduction of hospital formularies has not been aided by only nine consultants in clinical pharmacology having been appointed to district general hospitals. Some formularies have also been disappointing in their content, presentation, frequency of updating, flexibility to accommodate special needs, and feedback to prescribers about drug utilisation.

That priority has not been placed on the efficient production and maintenance of hospital formularies is surprising. In particular they are sometimes slow to advise on high cost, high risk drugs. Clear policies and adequate resources should exist for preparing, distributing, revising, and monitoring drug formularies. ${ }^{67}$ Most hospital doctors would appreciate regular information about their prescribing patterns and the relative costs of the drugs they use, and some will even accept regular measurements of how well their clinical team adheres to a formulary. How long will it be before hospital formularies are operational, accepted, and successful in every district health authority?

JAMES C PETRIE Professor of clinical pharmacology

ANDREW K SCOTT

Clinical Pharmacology Unit, Lecturer

Department of Medicine and Therapeutics,

University of Aberdeen,

Foresterhill,

Aberdeen AB9 2ZD 
1 Ridley H. Drugs of choice: a report on the drug formularies used in NHS hospitals. London: Social Audit 1986.

Crooks J. Drug epidemiology and clinical pharmacology: their contribution to patient care. $\mathrm{Br} f$ Clin Pharmacol 1983;16:351-7.

3 Collier J, Foster J. Management of a restricted drugs policy in hospital: the first five years' experience. Lancet 1985;i:331-3.

Swallow RD, Remington HStC, Standing VF. Ward pharmacy: a positive contribution to cost control. Pharmaceutical foumal 1985;235:722-3.

control. Pharmaceutical foumal 1985;235:722-3. Anonymous. American Society of Hospital Pharmacists (AHSP) comments conditions of participation in hospitals. Am $\mathcal{F}$ Hosp Pharm 1983;40:1037-41.

6 Anonymous. American Society of Hospital Pharmacists statement on the formulary systems. Am $\mathcal{J}$ Hosp Pharm 1983;40:1382-5.

American Society of Hospital Pharmacists technical assistance bulletin on hospital formularies. Am J Hosp Pharm 1985;42:375-7.

\section{Analgesia in the neonate}

The traditional reluctance to prescribe analgesic drugs to alleviate postoperative or other pain in neonates has recently been challenged by pain researchers. ${ }^{1}$ The main reasons for the reluctance to prescribe are doubts about whether neonates feel pain to the same extent as adults and concerns over the potentially harmful effects of powerful analgesics, particularly on the respiratory system. Most doctors have naturally based their opinions about whether neonates experience pain on clinical observation.

Even after major operations most babies who are not hypoxic or hypovolaemic settle down quickly and sleep peacefully for normal periods, especially if they can be fed early and orally. Burton and Derbyshire in 1958 described a severe withdrawal state in a young infant, which they called a "sleeping fit."' They postulated that it was caused by the excruciating pain of acute glaucoma, but this phenomenon has not been described elsewhere, and no one has suggested that this mechanism operates regularly in babies.

There are theoretical reasons for suspecting that neonatal perception of pain is reduced in proportion to the degree of myelination of the central nervous system. Neonates also have immature receptors and neurological pathway development, and nerve transmission in response to pain seems to be modified in immature nerve tissue. ${ }^{34}$ They also have circulating concentrations of $\beta$ endorphins higher than those in adults, and the immature blood brain barrier may allow these easier access to neuronal tissue. ${ }^{5}$ On the other hand, acute painful stimulation such as circumcision, which is often performed without anaesthesia in neonates in the United States, produces an obvious immediate response of breathholding, crying, and body movement: The observer is left in no doubt that the baby is experiencing pain.

Increasing acceptance that neonatal pain requires treatment has been shown from the results of a recent survey of members of the Association of Paediatric Anaesthetists ( $F$ Dorman, personal communication). More than half $(56 \%)$ of the 60 replying said that they used opioid analgesia in the neonate either occasionally or often. Though this is safe in babies being ventilated, it is associated with an important incidence of respiratory depression in those breathing spontaneously. This is probably because of altered pharmacokinetics and increased sensitivity to opioids related to the immature blood brain barrier and glucuronide metabolism. Apnoea in the neonate is potentially catastrophic, and even prolonged apnoea may remain undetected despite modern monitoring systems. ${ }^{6}$ Personnel skilled at tracheal intubation may not be immediately available, and hypoxic cerebral damage may occur. Infusions of opioids may be safer than bolus doses, and regional block may be safer still. That opioids may be dangerous in spontaneously breathing 0 neonates does not necessarily mean that they should not be used; it might be argued that the evidence of severe pain $\stackrel{\mathbb{Q}}{\Omega}$ justifies elective tracheal intubation and ventilation when $c$ opioids are to be given.

Little work has been published on the behavioural response to pain in infancy, and clearly more research is required. No single independent variable-whether it be crying, facial expression, body movement, or heart rate-is 0 likely to correlate closely with pain, since these variables are $\overrightarrow{\vec{F}}$ affected by so many other factors; but analysis of several $\stackrel{\oplus}{+}$ simultaneous responses may be helpful. Owens and Todt $\frac{0}{0}$ studied the effect of a heel lance on crying and heart rate $\overline{\bar{c}}$ in neonates and showed a statistically significant correlation $\vec{\nabla}$ despite wide baseline variability for each individual measure. ${ }^{7}$ A similar approach was used to study the effects of local anaesthesia on reactions to circumcision, ${ }^{8}$ and more recently $\overrightarrow{.}$ metabolic and hormonal responses to operations have been $\overrightarrow{\vec{\omega}}$ shown in the newborn. Only with the results of such research can we produce firm guidelines for using potent analgesics in neonates.

D J Hatch

Consultant in Anaesthesia and Respiratory Measurement,

Hospital for Sick Children,

London WC1N 3JH

1 Owens ME. Pain in infancy: conceptual and methodological issues. Pain 1984;20:213-30. 2 Burton IF, Derbyshire AJ. "Sleeping fit" caused by excruciating pain in an infant. Am f Dis Child 1958;95:258-60.

3 Jancso G, Kiraly E, Jancso-Gabor A. Pharmacologically induced selective denervation of $\vec{Z}$ chemosensitive primary sensory neurones. Nature 1977;270:741-3.

4 Lawson SN, Nickels SM. The use of morphometric technique to analyse the effect of neonatal capsaicin treatment on dorsal root ganglia and dorsal roots. $\mathcal{F}$ Physiol 1980;303:12P.

5 Sanner JH, Woods LA. Comparative distribution of tritrium labelled dihydromorphine between $\vec{C}$ maternal and fetal rats. F Pharmacol Exp Ther 1965;148:176-84.

Southall DP, Levitt GA, Richards JM, et al. Undetected episodes of prolonged apnoea and severe bradycardia in preterm infants. Pediatrics 1983;72:541-51.

7 Owens ME, Todt EH. Pain in infancy: neonatal reaction to a heel lance. Pain 1984;20:77-86.

8 Williamson PS, Williamson RN. Physiologic stress reduction by a local anaesthetic during newborn circumcision. Pediatrics 1983;71:36-40.

\section{Diet of young children and cardiovascular disease}

Should the diet of young children be changed to reduce their $\stackrel{8}{\circ}$ chances of developing cardiovascular disease? The National Advisory Committee on Nutrition Education (NACNE) 은 thought so in 1983 and produced nutritional guidelines for $N$ the whole population, ${ }^{1}$ but the Committee on the Medical or Aspects of Food Policy (COMA) in its recommendations of the next year specifically excluded children under $5 .^{2}$ This $\bar{N}$ split extends downwards, and community dietitians are keen N to promote healthy eating throughout the community, $\frac{\omega}{O}$ whereas paediatric dietitians are cautious about changing established feeding practices for children. ${ }^{34}$

Any important changes in dietary advice should benefit $\stackrel{0}{?}$ health, and any disadvantages, either predictable or un- $\frac{0}{7}$ foreseen, should not outweigh the putative benefits. The $\frac{\vec{D}}{\mathbb{D}}$ COMA recommendations meet these criteria for adults and $\frac{\rho}{\mathbb{D}}$ children over 5 . They state that the amount of food energy as $\varrho$ fat should not be more than $35 \%$, that the saturated to unsaturated fatty acid ratio should be about 0.45 , that fibre $ᄋ$ rich food should be increased and salt intake restrained, $\subseteq$ and that obesity should be avoided. Some of these rec- 